\title{
Turn Out to Turf Out?: Effects of Changes in Election Participation Rates on Election Outcomes
}

\author{
Eoin O’Malley*
}

School of Law and Government, Dublin City University, Ireland

\begin{abstract}
Participation in elections varies throughout Europe, and while politicians frequently claim that high turnout suits them, it cannot be true for all parties. Some authors have claimed that there is a positive correlation between turnout and support for left-wing parties; others have said that increased turnout aids challengers. Both these hypotheses have received support using data on the US, but evidence from data on Europe is less convincing. This article assesses these hypotheses and tests them using different data. While there is some support for the challenger hypothesis using data on the UK, the partisan hypothesis receives no support, probably because it was mis-specified in earlier tests.
\end{abstract}

\section{INTRODUCTION}

The 'one man, one vote' doctrine is pervasive in modern democracies. Whatever the skewed distribution of wealth, influence or access to media, everyone is equal in the polling booth. However, many people voluntarily absent themselves from voting. Could this make a difference to the outcomes of elections and hence policy outputs?

During elections politicians often claim that high turnout would benefit them or their party. But this is possibly selfserving - to convince voters that more people in the country favour them than their competitors. Political scientists have also made claims as to the effects of variation turnout. Tucker and Vedlitz [1] accepted, with reservations, the 'conventional wisdom' that turnout helps the Democratic Party in US elections, as did Piven and Cloward [2] and Nagel and McNulty [3]. McAllister [4] shows that higher turnout boosts support for the Australian Labor Party, and lower turnout favours the right-wing parties there. Pacek and Radcliff [5] in a multivariate analysis of cross-national aggregate data find a strong link between turnout and support for left-wing parties. White and McAllister [6] argue that low turnout in Russia may have a representation bias aiding those parties that are attractive to older, more conservative voters. Sinnott and Thomsen [7] and Sinnott [8] have argued that it was the turnout that contributed to the defeat and eventual acceptance of the Nice Treaty by Irish voters.

In contrast Ledyard [9] has argued that 'candidates act as if all voters were going to vote, but if candidates act that way voters may, in equilibrium, not vote'. In other words, changes in turnout will not have any policy or partisan composition effect. Palfrey and Rosenthal [10] noted that majorities have a greater incentive to free ride, and that if one belongs to a large majority, one will have even less

\footnotetext{
*Address correspondence to this author at the School of Law and Government, Dublin City University, Ireland; Tel: +353 1700 6473; E-mail: eoin.omalley@dcu.ie

Thanks to Michael Marsh and John Garry for comments on an earlier version of this paper
}

incentive to vote. Thus electoral majorities may be much smaller than the majority in the full electorate.

In this article I look at the electoral consequences of variation in turnout and test two of the hypotheses that appear in the political science literature. Using data on up to 23 countries from 1960-1998 I find that one of these hypotheses - that increased turnout benefits left-wing parties - has no empirical basis despite the findings of previous research. The second hypothesis - that decreased turnout helps incumbents - may hold in some limited situations and is worthy of further investigation. This is also tested using constituency level data from UK elections in 1997 and 2001.

\section{CONVENTIONAL WISDOM: HIGH TURNOUT BENEFITS THE LEFT}

The 'conventional wisdom' that rising turnout assists left-wing parties is intuitively appealing. Put simply, it consists of three propositions. The first is that people of lower socio-economic status (SES), the less well educated, and younger people are less likely to vote that those of higher SES, the better educated and older people. Second, the less well educated, younger people and people of lower SES are more likely to vote for left-wing parties. Thus, third, when turnout is lower, left-wing parties suffer as their natural voters are more likely to be the non-voters. As turnout rises, their supporters come into the voting electorate, gradually benefiting left-wing parties.

There is empirical evidence to support the first two parts of what is sometimes called the 'partisan bias effect' theory, and therefore its corollary. On the first part, Campbell et al. [11] in their classic work, found that abstention in the US was highest among those with low income and low education. Verba and Nie [12], also studying the US, saw SES as positively correlated with turnout. Again in the US, Rosenstone and Hansen [13] found that as the number of participants declines in any political activity, the first to drop out are disadvantaged citizens.

Although the class bias in turnout might be expected to be less in Europe and other advanced industrialised democracies than in less egalitarian societies such as the US, 
it still exists. Lipset (14: 182) found that throughout Europe the better educated vote more often than the less well educated and 'higher status persons more than lower' status people. Lijphart [15] cited a large literature which shows this. One interesting work by Ackaert and de Winter [16] demonstrates that if compulsory voting were ended in Belgium turnout would drop by a third and result in a strong class bias in abstention rates. In the UK, Crewe, Fox and Alt (17: 53) also found that working class people (subjectively measured) and those on low income are much less likely to vote or be active in politics.

Marsh [18] made the distinction between long and shortterm non-voters. Short-term non-voters are those who usually vote but do not vote in a given election, whereas the long-term non-voters are disinclined from voting at all. He found that long-term non-voters in Ireland are more likely to be unemployed and half as likely to be middle class than those who regularly vote.

If the class bias in participation is more pronounced in the US than in Europe, then the class bias in vote choice might be more pronounced in Europe than in the US. The second part of the thesis requires that voters' choices are determined to some extent by class (or youth, or education). The class cleavage has been one of the mainstays of electoral behaviour. So much so that Lipset (19: 230) could say that 'one of the principal generalisations which can be made is that parties are primarily based on either the lower classes or the middle or upper classes'.

However, there has been a decline in class voting. This seems evident from the movement to the centre by many left-wing political parties in pursuit of middle-class voters. Left-wing parties in Spain, UK, Ireland, Italy, and whichever country one looks at, seem to favour a market-driven message. Meanwhile the populist messages given by rightwing parties are increasingly attractive to working-class voters. Nieuwbeerta and Ultee [20] argue that using whichever indicator, the Alford Index [21] or log-odds ratio measure, class voting has significantly declined. Still, class influence persists and one could not say it is completely independent of party choice. Evans (22: 333) contends that 'the only consistent and robust evidence of declining classvote relations is in Scandinavia'. He calls for a reappraisal of the relationship between class and the vote rather than the relationship's obituary.

In any case, as the first two components are true (at least at times), logically the next component should be true. Changes in turnout should co-vary positively with changes in support for left-wing parties. Even if class voting has declined, the theory should hold at least some of the time. Evidence in the US, where the idea was developed, is patchy. However, Pacek and Radcliff (5: 139) found in their empirical analysis 'that the left share of the vote increases by about one third of a point for every percentage point increase in turnout'. As their dataset was extensive both over space (19 countries), and time (1950-1990), one can be impressed by the evidence of their models.

This partisan bias effects hypothesis is simple and neat, but unfortunately it is also simplistic. There are theoretical problems with the hypothesis and methodological problems with how it has been tested. I deal with the methodological problems below, but first give an alternative view of the hypothesis.

\section{THEORETICAL CHALLENGES}

This 'partisan bias effects' hypothesis has not gone unchallenged. A revisionist view of turnout effects on the left criticised the partisan bias effect thesis on theoretical grounds. Campbell et al. [11] were among the first to point out that voters' likelihood to vote and voters' partisan predisposition are not independent, as the partisan bias effects theory implicitly assumes, (see DeNardo [23] for formal proof that this a necessary assumption).

If these two variables are not independent then it does not necessarily follow that if turnout goes up, support for leftwing parties also will. Voters at the margins (between voting and not voting) may also have a weaker predisposition to support their 'natural' party, i.e. the party for which they would be expected to vote: for a working class person, this is a left-wing party. The rates of defection - that is, the rate at which voters stray from their 'natural' predispositions 'vary with the level of turnout' (23: 413).

Voters that barely make it to the polling booth will be less loyal to their predispositions. So a working class voter who is unlikely to vote might more easily switch her vote to another party if she votes. Therefore one would not expect, as turnout increases that support for the left would necessarily also rise.

Grofman, Owen and Collet (24: 359) have argued in favour of a competition effect in which turnout will be highest when the competition is close. There is evidence of a correlation between turnout and margin of victory, which might be quite different to expected margin of victory, the phenomenon that would motivate the electorate to vote. Franklin (25: 163] finds evidence that 'margin of victory reduces turnout by about one-tenth of a percentage point for each $1 \%$ that the leading party runs ahead of its major competitor'. Denver and Hands [26] found that marginality was a significant predictor of constituency turnout in the UK.

From this Grofman, Owen and Collet go on to hypothesise that high turnout 'will appear to benefit Democrats only in situations where Republicans are incumbents' or as DeNardo (23: 418) put it 20 years earlier 'campaigners for the minority party should celebrate when the fickle periphery turns out in force'. Generalising beyond the US, the challenger hypothesis is that low turnout will tend to benefit incumbents and increases in turnout will tend to benefit the challenging parties or candidates.

Why should this be the case? We can assume that potential voters can get 'excited' by alternative governments or challengers to incumbency, either positively or negatively. Where no (viable) alternative exists, the election will not be 'exciting'; foregone conclusions are dull. If a challenger excites strong positive feelings among some significant part of the electorate to the extent that the challenger becomes a viable alternative to the incumbent, the incumbent and the challenger should increase campaign activity thereby increasing political mobilisation and turnout. The 'fickle' marginal voters may be more likely to be excited by and vote for the party/ candidate with the electoral tide running in its favour, i.e. the challenger. 
There are some clear cases of this phenomenon seemingly at work. In the UK, the elections in 1974 and 1979 that brought about changes of government had increased turnouts $(+6.7$ percent and +3.1 percent respectively). The British Labour Party's successful defence of their position in 2001 occurred with a dramatic fall in turnout. In Spain, the election that put the Socialist party in government in 1982 had an increase in turnout of over 10 percent, whereas the 2000 election in which the right-wing Popular Party maintained power occurred with a turnout 10 percent down on the previous election. Likewise Bill Clinton's initial election saw an increase in turnout and his retention of the US presidency coincided with a dramatic drop. In 2007 the Polish party, Civic Platform ousted the incumbent Law and Justice party with nearly a 14 percent increase in turnout.

Obviously incumbents may be vulnerable even without the arrival of a new and exciting challenger. The incumbent might be there as the product of a very close result at the previous election, so it would seem natural that the existing challenger is viable. Increased turnout is not going to be necessarily good or bad for the incumbent in this situation. Thus the expected relationship may not be strong or deterministic.

The difficulty with the 'challenger' supposition, as stated, is that it assumes that incumbents have marshalled all of their potential voters to the polling booth in the previous election. According to this logic a challenger merely has to rouse enough people who previously abstained to vote to overtake the incumbent. Of course, as Ledyard [9] has argued, incumbents' majorities may be smaller than they might be given full participation. This is because incentives to abstain are greater for those who belong to the winning side.

Another countervailing factor is the effect of campaigning. Strong challenges to incumbents will initiate an increase in campaigning that should increase turnout, but may not affect the incumbents' support or margins of victory because the original levels of support and margins of victory were artefacts of previous campaigns. The ensuing campaign can motivate supporters of incumbents as well as challengers to vote; so higher turnouts may even increase incumbents' vote and proportion of the vote.

This approach assumes that changes in turnout can assist the incumbent, the challenger, or neither (by having no effect), but not both simultaneously. Where there are only two 'effective' parties or candidates this is true, because the electoral competition is a zero-sum game between the incumbent and challenger. However, in multi-party/ multicandidate systems this is not the case, as both the challenger and incumbent can increase their proportion of votes. Thus, the challenger hypothesis might work best in countries or elections where there is a low 'effective number of parties' (ENP) or there is a plain choice of government, the link between voting and choosing or removing governments is clear.

\section{This Leaves Two Hypotheses for Testing}

a. As turnout rises, left-wing supporters come into the voting electorate, benefiting left-wing parties. b. Low turnout will tend to benefit incumbents and increases in turnout will tend to benefit the challenging parties or candidates where the ENP is low or there is a clear link between voting and who governs.

\section{DATA, METHOD \& ANALYSIS}

Of the two rival hypotheses on the effects of turnout only the first has ever been tested on comparative data. However, the research by Pacek and Radcliff [5] as well as having theoretical flaws discussed above, also has methodological flaws. The second hypothesis has only been tested on US data. I deal with the partisan effects hypothesis model first.

\section{PARTISAN EFFECTS HYPOTHESIS}

Pacek and Radcliff test the hypothesis that increases in turnout lead to higher support for left-wing parties by regressing the percentage vote for left-wing parties on the turnout in each election. Their results, it is claimed, demonstrate 'that the left share of the vote increases by about one third of a point for every percentage point increase in turnout' (5: 139).

In Pacek and Radcliff's first model they include just raw turnout and country dummy variables to explain the support for the left $\mathrm{i}^{\mathrm{i}}$. With this seemingly parsimonious model they account for an impressive 78 percent of the variation in support for left-wing parties and turnout is a significant and positive predictor of support for left-wing parties. They then added the extent of class voting in each country and an interaction of class voting and turnout, both of which are significant. The expectation here is that the effects of turnout will be more important where class voting is high.

However, Pacek and Radcliff, following scholars studying the US, claimed to be looking at the effects of turnout change on movement in support for left-wing parties. Yet what their models (and the models of the effects of turnout in US politics) actually explain is overall level of support for left-wing parties. It is possible that there is a causal relationship between turnout and support for left-wing parties, but the correlation one sees could also be due to other factors. Also, data on turnout are not valid for comparison across countries as there are different measures of turnout, and the accuracy of using registers of electors to measure the electorate has been shown to be problematic for Ireland at least [27]. For this additional reason it is better to look at changes in turnout which are less affected by the inaccuracies of the base figures.

Next their models are replicated on new data, and in order to investigate the effects of changes in turnout on changes in left support a new model is constructed with marginal changes in turnout and left support where previously only overall levels of support and turnout were used. These models are replicated using data compiled and collated by Armingeon, Beyeler and Menegale [28] with the unit of analysis as each election in each country ${ }^{\text {ii }}$ from 1960 to 1998 . In total there are 257 cases. The sources for the data on party support are Mackie and Rose [29] and the EJPR

\footnotetext{
${ }^{\mathrm{i}}$ The country dummy variables are included to account for the overall level of left support in the pooled dataset.

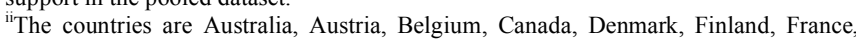
Germany, Greece, Iceland, Ireland, Italy, Japan, Luxembourg, Netherlands, New Zealand, Norway, Portugal, Spain, Sweden, Switzerland, UK and USA.
} 
yearbooks. Parties were assigned as left-wing according to Lane, McKay and Newton [30]. It should not matter that this ignores the movements of parties to the centre, as what should be important is the partisan direction of the party within its own system.

To measure class, more reliable and valid data are now available. I use the Thomsen Index, which uses the ratio of the odds for manual workers to vote for left-wing parties rather than right-wing parties compared to the odds of a nonmanual worker to do the same. This is preferable to the Alford Index because the index is not affected by the overall level of support for the party $(31: 28)$. The data come from Nieuwbeerta and de Graaf (31: 32-3) who give values for class voting by decade for each country.

Using this dataset the OLS regression model with level of turnout explains almost 90 percent of variation in the dependent variable and turnout is significant, although the coefficient is smaller than that reported by Pacek and Radcliff. In the model that controls for class and includes the turnout/ class interaction term, none of the substantive coefficients is significant, but the R-squared is still very high, mainly due to the inclusion of the country dummy variables. Indeed when only the country dummy variables are included the adjusted R-squared is .88 .

It seems clear that there is a relationship between turnout and support for left-wing parties. However, given the problems with the theoretical expectations outlined above, the causal nature of the relationship may be spurious. Another variable may affect both turnout and left-wing support. It is possible, for instance, that in countries with high levels of equality and education that one simultaneously sees high support for left-wing parties and high turnout, as where a society is highly equal it may be due to the policies of left-wing governments, which would indicate that the left is strong. The relationship could be that strong support for the left causes greater equality, which in turn leads to higher turnout. Income, wealth and education have been suggested as important variables at an individual level by Lijphart (1997).

This can be tested. The Gini coefficient is the most common measure for equality and here the OECD's Gini index (measured between 0 and 100, where 0 indicates complete equality) is used. Equally where the mean education level is high, turnout might be expected to be higher, but mean education may be higher because of egalitarian policies pursued by left-wing parties in government. Here an 'education' variable measures the countries' difference from an OECD country mean (of 500) for attainment in mathematics among 15 year olds. Maths is used as it is the most easily comparable subject, and less affected by cultural differences. Country dummy variables are included in the analyses because of the pooled crosssectional dataset even though there are no expectations of temporal trends or variation.

With these variables in the model the adjusted R-squared is .94. In this model turnout is no longer significant. The variables measuring equality are significant and in the right direction. This would indicate that the positive relationship between support for left wing parties and turnout might exist but that there is an intervening third variable, equality. Rather than turnout 'causing' high levels of support for left leaning parties, support for left-wing parties may lead to (or may flow from) greater equality. Equality, one could plausibly expect to be associated with efficacy, which has been shown (at the individual level) to correlate with turnout.

However, this has said nothing about whether changes in turnout lead to changes in support for left-wing parties. So if one tests this hypothesis, what does one find? In the resulting regression of change in left-wing support on change in turnout, the turnout coefficient was not significant, and the

Table 1. Explaining the Level of Support for Left-Wing Parties

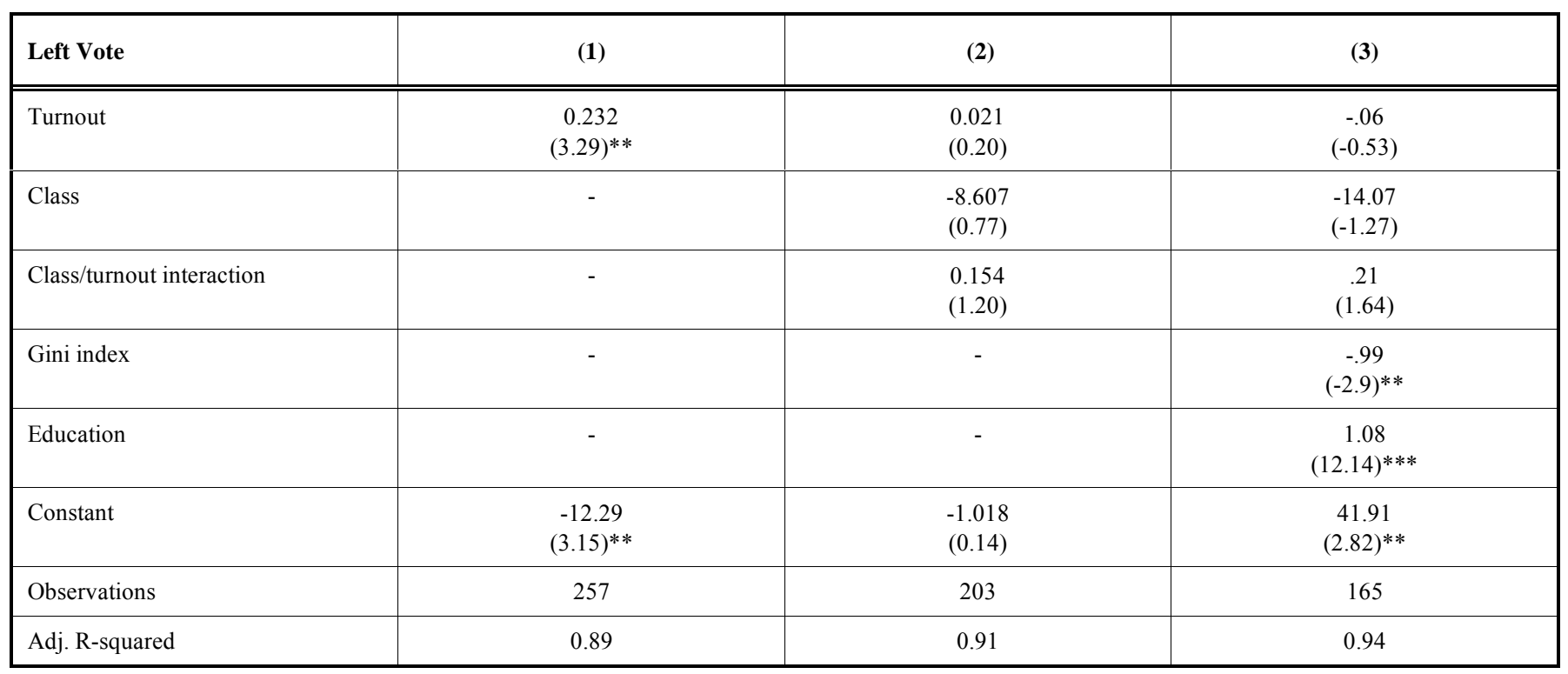

Absolute value of $t$ statistics in parentheses.

*significant at $5 \%$ level; ** significant at $1 \%$ level.

Output for country dummy variables is omitted from the table. The absence of data for various countries means that the number of cases drops. The complete datasets and Stata 'do files' are available from the author. 
Table 2. Incumbent Success in British Elections in 1997 and 2001

\begin{tabular}{|l|c|c|}
\hline & $\Delta$ support for incumbent & Incumbent holds seat=1 \\
\hline \hline$\Delta$ Turnout & $\begin{array}{c}-.331 \\
(-3.31)^{* *}\end{array}$ & $\begin{array}{c}-.175 \\
(-5.21)^{* * *}\end{array}$ \\
\hline Year dummy 2001=1 & $\begin{array}{c}3.56 \\
(4.56)^{* * *}\end{array}$ & $(4.43)$ \\
\hline Turnout & $\begin{array}{c}.091 \\
(2.18)^{*}\end{array}$ & - \\
\hline Constant & -12.35 & -.059 \\
& $(-3.75)^{* * *}$ & $(-0.29)$ \\
\hline Observations & 1280 & 1280 \\
\hline Adj./ Pseudo R-squared & .076 & .179 \\
\hline
\end{tabular}

R-squared was below .01 (not reported). Various models were specified to investigate the possibility that the two may be related, but no effect was found and the adjusted Rsquared never rose above .04. These results are clear: the answer to the question 'Do changes in turnout help the left?' is, probably not. This result accords with a study by Bernhagen and Marsh [32] which imputes individual level data to simulate full turnout elections.

\section{CHALLENGER HYPOTHESIS}

The next hypothesis, one for which some support might be expected, concerns the effect of changes in turnout on support for incumbents. Higher turnout may help challenging parties or candidates to create a 'bandwagon effect' as longterm non-voters tend to go the polls to support a challenger. Change in turnout should have a clearer effect where the effective number of parties is low or voting has an effect on the choice of government.

If this hypothesis were true one would expect that, ceteris paribus, support for incumbents- the government parties goes down as turnout increases. However, to test this comparatively one must overcome problems such as identifying the challenger parties. In the coalition systems of western Europe this is not a simple task. Might not a junior coalition partner be a challenger to the more senior parties in government? Even the largest party in a coalition government may be seen as challengers in an election. One also has the problem that in many countries turnout varies very little due to compulsory voting or perhaps other reasons.

Initial tests (not shown) using this data indicate that change in turnout is not an important predictor of changes in support for government parties. But given the countervailing forces at work this may not be surprising. A useful test of the hypothesis would be to use a most likely case, that is, a case one would expect the hypothesis to work and an absence of fit would cast strong doubts on the hypothesis (33: 121). British constituencies offer an ideal (but less complete) case to test the proposition because it uses a plurality election rule in single seat constituencies so there is no second place. Therefore voters may strategically centre their support on two candidates.
Here I look at the change in two elections 1997 (change from 1992) and 2001 (change from 1997). In these elections there were 641 constituencies in Britain, so the total number of observations is $1280^{\mathrm{iii}}$. These cases are also useful because these elections were quite different; in one election there was a good deal of change from incumbents (1997) and in the other (2001) there was relatively little turnover. This is a most likely case, if one fails to find a significant effect here, one should surely question this hypothesis.

The first model is an OLS regression with a dependent variable, change in incumbent support (measured in percentage change of vote received) regressed on the change in turnout (also measured in percentages). To take account of the different elections, a dummy variable is introduced, with 2001 coded as 1 . One would expect that this coefficient would be positive as there was a much lower legislative turnover in 2001 than in 1997, the year in which many Conservative MPs were defeated. This variable will control for these differences. The advantage of using constituency data is evident here in that they take into account incumbent Labour MPs in 1997 and incumbent non-Labour MPs in 2001. A third variable controls for the level of turnout (measured in percentages).

Table 2 below displays the results of this model. The two coefficients are significant and in the expected direction. The strength of the turnout change coefficient is encouraging. It means that for a one-percentage point increase in turnout, there was a drop in support for the incumbent by a third of a percentage point. In the UK at least increased turnout is detrimental to incumbents. This was the case even when controlling for the different elections. The level of turnout is also statistically significant, and indicates that higher overall turnout seems to be good for incumbents.

Another test of the hypothesis is to look at whether or not the incumbent MPs win their election. A logistic regression model with the same specification except that the dependent variable is dichotomous measuring whether the incumbent held on to his/ her seat (coded as 1). The second model in

iii I removed two extreme outliers, Tatton and Wyre Forest where independents won in 1997 and 2001 respectively. These candidates were unopposed by some parties. Northern Ireland is not included. 
Table 2 shows that a decrease in turnout has a negative effect on the probability of holding on to one's seat. Again the variable controlling for the election is significant and in the expected direction.

Obviously the challenger hypothesis is tested on just two general elections whose unique features peculiar to Britain may be important (although these effects are controlled for). One therefore would not wish to make general claims on the basis of this analysis. However, this does represent prima facia evidence for the challenger hypothesis. Another word of caution is necessary. These tests were carried out on aggregate data and the possibility of an ecological fallacy remains, i.e. that the relationship observed at group level may not apply at the individual level [34]. So it may not be that the 'new' voters are supporting 'new' challengers, rather that the new or marginal voters are being drawn into the contest to support an incumbent and that 'regular' voters are switching. However there are good theoretical reasons to expect that new voters are motivated to support new challengers. Moreover it is not salient to the overall argument which is that changing levels of participation yield changing but predictable support for candidates/ parties however this is constructed. More analysis of individuallevel data on non-voters and marginal voters is needed to understand the true effects of marginal voters and nonvoters. It is important to note that this hypothesis is mildly supported by the Bernhagen and Marsh [32] analysis on individual level data.

\section{CONCLUSION}

Academics have given a good deal of attention to studying the causes of turnout, and its alleged decline. Turnout may reflect people's engagement in politics and society, thus we are right to be concerned about and study changes in the level of turnout. However, relatively little attention has been brought to bear on discovering if changes in turnout make any difference.

This paper has looked at two hypotheses; one of which, the partisan effects hypothesis, is theoretically problematic. Most of the previous empirical support for the thesis was due to poorly specified testing of data - some scholars proposed that turnout changes had an effect on support for left-wing parties, whereas their tests investigated the relationship between overall turnout and overall support for left-wing parties. When specified differently and tested on comparative data this hypothesis receives no empirical support.

The second hypothesis is that challengers benefit from increases in turnout, because marginal voters will tend to support 'new' and 'exciting' electoral phenomena. Again this hypothesis is problematic as there are possible countervailing effects. However if it were to be a plausible explanation, it should work in an effective two-party system, such as the UK. This hypothesis was tested on constituencylevel data and the results supported this hypothesis. The empirical analyses here can be replicated and extended using other data from newer democracies such as in Asia and South America.

Overall this tell us that changes in electoral participation rates do make a difference and that we expect to see increases in turnout benefit challengers. The introduction of compulsory voting would have real effects, though not to support left wing parties as much of the literature suggests but to support challengers. Therefore it is highly unlikely that incumbent government would introduce such a regime, or even commit resources to motivating across the board turnout. Indeed this does throw up the puzzle as to why any government would attempt to encourage broad-based turnout, except among its own supporters. So we might expect to see initiatives such as 'Rock the Vote' would be more heavily supported by challengers regardless of their political hue.

\section{REFERENCES}

[1] Tucker HJ, Vedlitz A. Does heavy turnout help Democrats in presidential elections? Amer Polit Sci Rev 1986; 80: 1291-1304.

[2] Piven FF, Cloward RA. Why Americans Don't Vote. New York: Pantheon Books; 1988.

[3] Nagel JH, McNulty, John E. Partisan Effects of Voter Turnout in Presidential Elections. Am Polit Res 2000; 28: 408-429.

[4] McAllister I. Compulsory voting, turnout and party advantage in Australia. Politics 1986; 21: 89-93.

[5] Pacek A, Radcliff B. Turnout and the vote for left of centre parties: a cross-national analysis. Brit J Polit Sci 1995; 25: 137-143.

[6] White S, McAllister I. Turnout and representation bias in postcommunist Europe. Polit Stud 2007; 55(3): 586-606.

[7] Sinnott R, Thomsen R. Why so many people did not go out to vote on the Nice Treaty is the question. The Irish Times 2001 23rd June.

[8] Sinnott R. No vote stagnated while Yes side gained hugely. The Irish Times 200221 st October.

[9] Ledyard JO. The pure theory of large two-candidate elections. Public Choice 1984; 44: 7-41.

[10] Palfrey T, Rosenthal H. A strategic calculus of voting. Public Choice 1983; 41: 7-53.

[11] Campbell A, Converse PE, Miller WE, Stokes DE. The American Voter. Chicago: University of Chicago Press; 1960.

[12] Verba S, Nie J. Participation in America: Political Democracy and Social Equality. New York: Harper \& Row; 1972.

[13] Rosenstone SJ, Hansen JM. Mobilization, Participation and Democracy in America. New York: Macmillan; 1993.

[14] Lipset SM. Political Man: The social bases of politics. Garden City, New York: Doubleday; 1960.

[15] Lijphart A. Unequal Participation: Democracy's unresolved dilemma. Amer Polit Sci Rev 1997; 91: 1-14.

[16] Ackaert J, de Winter L. Electoral Absenteeism and Political Absenteeism in Belgium. In: Annual Conference of the American Political Science Association; 1996; San Francisco; 1996.

[17] Crewe I, Fox T, Alt J. Non-voting in British general elections 1966- October 1974. In: Crouch C, editor. British Political Sociology Yearbook. London: Croom Helm; 1977.

[18] Marsh M. Accident or design? Non-voting in Ireland. Irish Polit Stud 1991; 6: 1-14.

[19] Lipset SM. Political Man: The social bases of politics. Expanded ed. Baltimore: Johns Hopkins University Press; 1981.

[20] Nieuwbeerta P, Ultee W. Class voting in western industrialised democracies, 1945-1990: systematising and testing explanations. Eur J Polit Res 1999; 35: 123-160.

[21] Alford R. Party and Society: The Anglo-American Democracies. Westport: Greenwood Press; 1963.

[22] Evans G, editor. The End of Class Politics? Class Voting in Comparative Context. Oxford: Oxford University Press; 1999.

[23] DeNardo J. Turnout and the vote: the joke's on the Democrats. Am Polit Sci Rev 1980; 74: 406-20.

[24] Grofman B, Owen G, Collet C. Rethinking the partisan effects of higher turnout: So what's the question? Public Choice 1999; 99: 357-76.

[25] Franklin MN. The dynamics of electoral participation. In: LeDuc L, Niemi R, Norris P, editors. Comparing Democracies 2. Elections and Voting in Global Perspective. 2nd ed. Thousand Oaks: Sage; 2002.

[26] Denver D, Hands G. Marginality and turnout in general elections in the 1970s. Brit J Polit Sci 1985; 15: 381-8. 
[27] O'Malley E. Apathy or Error? Questioning the Irish register of electors to question turnout decline. Irish Polit Stud 2001; 16: 179190.

[28] Armingeon K, Beyeler M, Menegale S. Comparative Political Data Set 1960-98. Berne: Institute of Political Science, University of Berne; 2000.

[29] Mackie TT, Rose R, editors. The International Almanac of Electoral History. 3rd ed. London: Macmillan; 1991.

[30] Lane J-E, McKay D, Newton K. Political data handbook: OECD countries. 2nd ed. Oxford: Oxford University Press; 1997.
[31] Nieuwbeerta P, Graaf NDd. Traditional class voting in twenty postwar societies. In: Evans G, editor. The End of Class Politics? Oxford: Oxford University Press; 1999.

[32] Bernhagen P, Marsh M. The partisan effects of low turnout: Analyzing vote abstention as a missing data problem. Elect Stud 2007; 26 (3): 548-560.

[33] George AL, Bennett A. Case Studies and Theory Development in the Social Sciences. London: MIT Press; 2005.

[34] Freedman DA. Ecological inference and the ecological fallacy. In: Smelser NJ, Baltes PB, editors. International Encyclopedia of the Social and Behavioral Sciences. Amsterdam: Elsevier; 2001. p. 4027-30.

(C) Eoin O'Malley; Licensee Bentham Open.

This is an open access article distributed under the terms of the Creative Commons Attribution License (http://creativecommons.org/licenses/by/2.5/), which permits unrestrictive use, distribution, and reproduction in any medium, provided the original work is properly cited. 